\title{
Total synthesis of cis, cis-ceratospongamide
}

\author{
Zhiyong Chen, ${ }^{\mathrm{a}}$ Jingen Deng, ${ }^{\mathrm{a}}$ and Tao Ye $\mathrm{Ya}^{\mathrm{a}, \mathrm{b}^{*}}$ \\ ${ }^{a}$ Department of Chemistry, The University of Hong Kong, Pokfulam Road, Hong Kong, China \\ ${ }^{b}$ Open Laboratory of Chirotechnology of the Institute of Molecular Technology for Drug \\ Discovery \& Synthesis and Department of Applied Biology \& Chemical Technology, \\ The Hong Kong Polytechnic University, Hung Hom, Kowloon, Hong Kong, China \\ E-mail: bctaoye@inet.polyu.edu.hk
}

\section{Dedicated to Professor M. Anthony McKervey on his $65^{\text {th }}$ birthday}

(received 05 Mar 03; accepted 04 Jun 03; published on the web 10 Jun 03)

\begin{abstract}
A total synthesis of cis, cis-ceratospongamide 1 was accomplished via 4+3 fragment condensation, macrolactamization and subsequent cyclodehydration. Macrolactamization of both linear peptides $\mathbf{4 a} \& \mathbf{4} \mathbf{b}$ produced the corresponding cyclopeptide $\mathbf{3}$ as a mixture of two conformational isomers (cis, cis $\mathbf{3 a}$ and cis, trans $\mathbf{3 b}$ ). Further oxazoline ring closure furnished the cis, cis-ceratospongamide $\mathbf{1}$ which is identical to the natural product.
\end{abstract}

Keywords: cis, cis-Ceratospongamide, synthesis, conformation, macrocyclization

\section{Introduction}

A large number of natural products containing conformational constraints such as oxazole, thiazole and proline or $\mathrm{N}$-alkyl amine have been isolated from bacteria, fungi, plants and marine organisms, over the last couple of decades. The cytotoxic and antineoplastic activities that they exhibit, as well as the possibility of their acting as metal chelating metabolites, have inspired a considerable number of structural and synthetic studies. ${ }^{1}$

Recently, the isolation of two special conformationally stable cyclic heptapeptides, cis, cisand trans, trans-ceratospongamides $(\mathbf{1}, \mathbf{2})$ have attracted our attentions. ${ }^{2}$ These two conformationally stable isomers were isolated from the marine red alga (Rhodophyta) ceratodictyon spongiosum by Gerwick and co-workers in the 2000. Both conformationally stable isomers of ceratospongamide contain two phenylalanine residues, one proline-thiazole amide unit, and one proline-isoleucine dipeptide further linked to an oxazoline segment. Amazingly, these two conformational isomers showed completely different bioactivities; the trans, transisomer exhibits potent inhibition of $\mathrm{SPLA}_{2}$ expression in a cell-based model for anti- 
inflammation ( $\mathrm{ED}_{50} 32 \mathrm{nM}$ ), whereas the cis, cis-isomer is inactive. ${ }^{2}$ Intrigued by the unusual molecular architecture of ceratospongamides, and the different bioactivity that the conformation caused, we have carried out the total synthetic studies. In an early communication, ${ }^{3}$ we have reported our preliminary results towards the total synthesis of ceratospongamide. ${ }^{4}$ We now provide details of this synthesis involving two alternative macrocyclization protocols for the construction of the penultimate cyclopeptide 3, establishment of the conformational behavior of cyclopeptide $\mathbf{3}$, and cyclodehydration to furnish the final natural product.

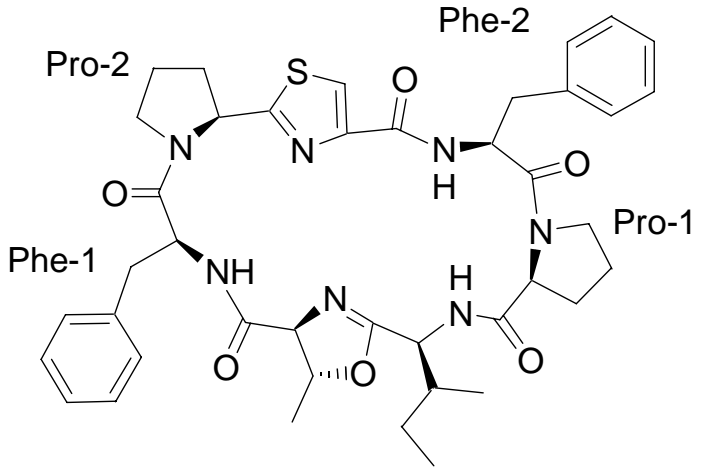

cis, cis-ceratospongamide $\mathbf{1}$

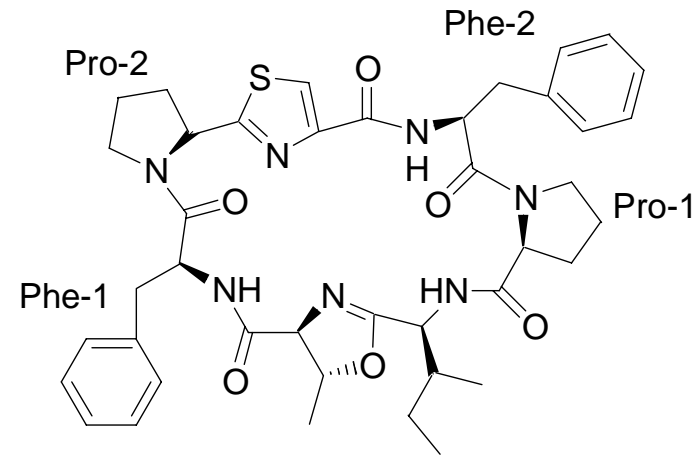

trans, trans-ceratospongamide 2

\section{Figure 1}

\section{Results and Discussion}

The trans-oxazoline ring is an acid-sensitive and readily opened moiety. ${ }^{5}$ Furthermore, the propensity of the stereogenic centre adjacent to the oxazoline ring undergoes facile epimerization suggested that the oxazoline ring closure should be delayed until the final step. ${ }^{6}$ This consideration led us to target the penultimate cyclopeptide $\mathbf{3}$ as the most advanced intermediate and installation of the oxazoline ring was anticipated to be performed in the final step. At the outset of this work, we also proposed to prepare cyclopeptide $\mathbf{3}$ by macrocyclization of the linear peptides $\mathbf{4 a}$ and $\mathbf{4 b}$ (Scheme 1). This macrocyclization processes were planned as we believed these disconnections would minimize epimerization and steric hindrance at the C-terminus. In addition, the hydrogen-bond inducing turn-forming effect might occur in both linear precursors $\mathbf{4 a}$ and $\mathbf{4 b}$, which should facilitate the macrocyclization process. ${ }^{1,7}$ Both peptides $\mathbf{4 a}$ and $\mathbf{4 b}$ can be prepared through a [4+3] fragment condensation of tetrapeptide 5 and a thiazole containing tripeptide 6, which can be further disconnected to give 2-(trimethylsilyl)ethyl carbamate (Teoc) protected phenylalanine methyl ester $\mathbf{7}$ and the thiazole methyl ester $\mathbf{8}$. 


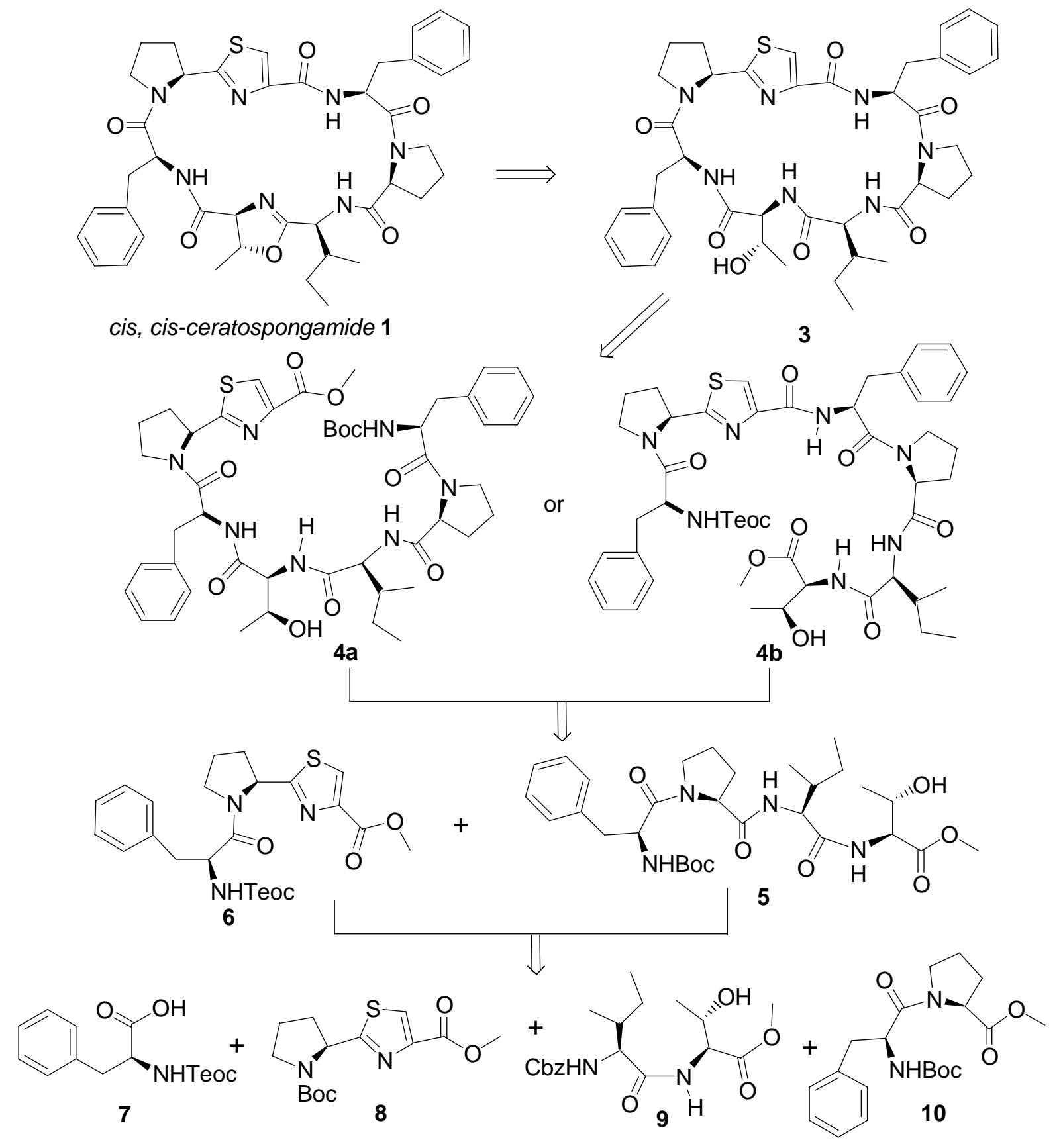

\section{Scheme 1}

Synthesis of the thiazole methyl ester 8 could be achieved by oxidation of the corresponding thiazoline to thiazole. Since the amino acid-derived thiazolines have propensity for epimerization under either basic or acidic conditions, so any cyclodehydration reaction leading to thiazoline and its further oxidation reaction to thiazole must be carried out under near-neutral conditions. Based on our previous experience obtained in the synthesis of amino acid-derived thiazolines and thiazoles, ${ }^{8}$ we decided to employ the Wipf procedure for the preparation of Boc- $L$-Proline- 
derived thiazole 8 (Scheme 2). Thus, coupling of the the L-Boc-proline and L-serine methyl ester afforded dipeptide 12 in 89\% yield. The hydroxy group in 12 was protected as its tertbutyldimethylsilyl ether affording dipeptide 13 which was smoothly converted into thioamide 14 with Lawesson's reagent. ${ }^{9}$ Subsequent removal of the silicon protecting group and reaction with Burgess reagent yielded thiazoline 16. Oxidation of thiazoline $\mathbf{1 6}$ by use of actived $\gamma$-manganese dioxide produced the thiazole derivative 8 in $44 \%$ overall yield. ${ }^{10}$ Following removal of the Boc group in thiazole segment $\mathbf{8}$ using TFA in dichloromethane, this residue was then condensed with Teoc-L-phenylalanine (7) in the presence of EDCI and HOBt to provide tripeptide 6 in $84 \%$ yield.

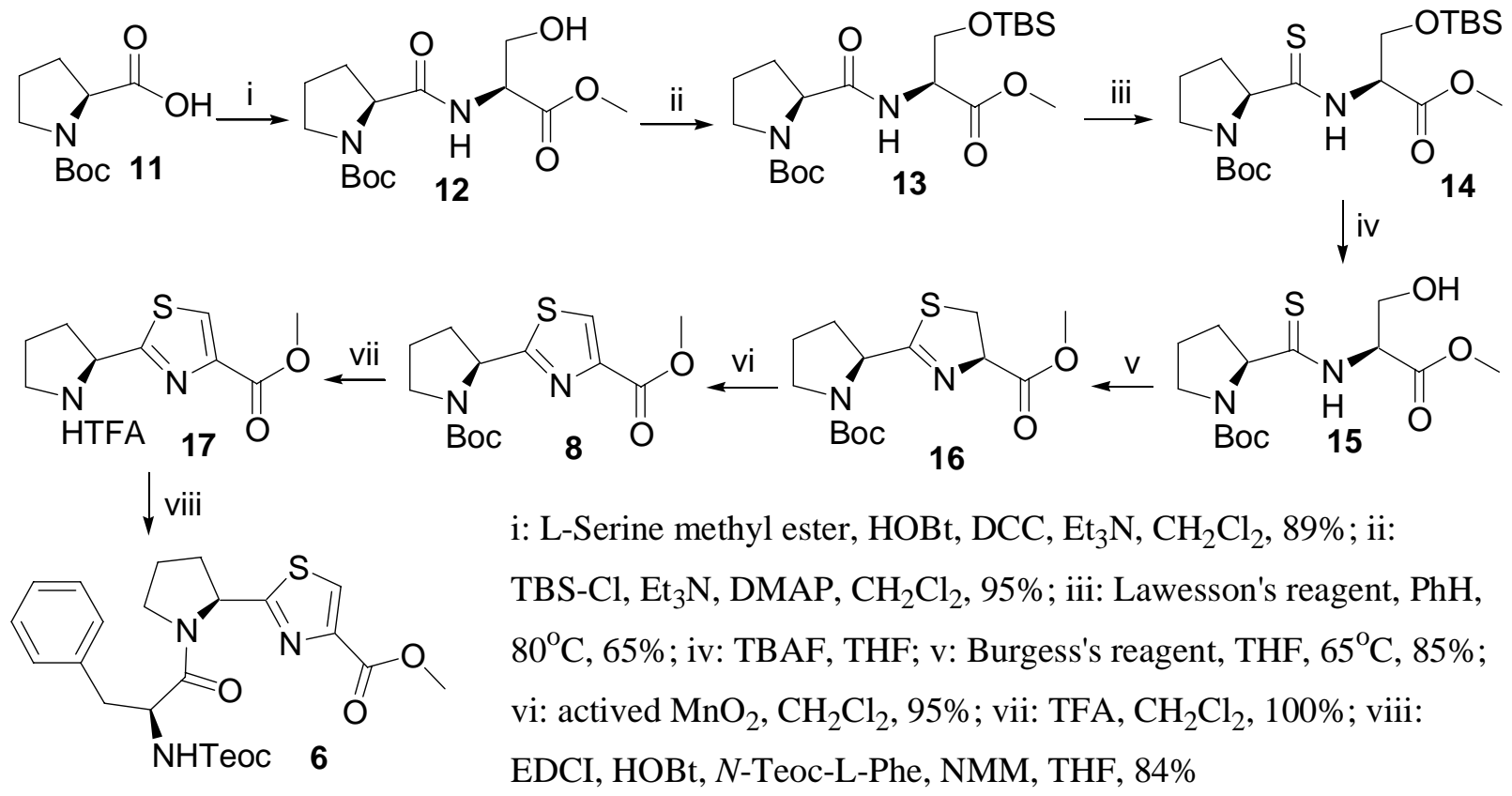

\section{Scheme 2}

Synthesis of the fragment $\mathbf{5}$ is shown in Scheme 3. Dipeptide fragment $\mathbf{9}$ is easily prepared in good quantity according to Wipf's procedure. ${ }^{11}$ Thus, Cbz-protected L-isoleucine was condensed with L-threonine methyl ester in the presence of DCC and HOBt gave dipeptide $\mathbf{1 9}$ in 89\% yield. This dipeptide was then treated with Burgess's reagent provided oxazoline 20 in $78 \%$ yield. Subsequent mild hydrolysis of the resulting peptidyl oxazoline with $0.3 \mathrm{M} \mathrm{HCl}$ gave the O-acyl amine which underwent in situ acyl migration to afford the desired dipeptide $\mathbf{9}$ in 51\% yield over two-steps. The Cbz protecting group in this dipeptide was removed by hydrogenolysis over $10 \%$ $\mathrm{Pd} / \mathrm{C}$ in methanol to give the corresponding amine $\mathbf{2 1}$ ready for use in next step. The complementary coupling partner 22 was prepared by condensing of L-Boc-phenylalanine with Lproline methyl ester using DCC and HOBt in 90\% yield. Saponification of dipeptide 22 with lithium hydroxide furnished the necessary carboxylic acid 23 in $98 \%$ yield. The coupling of 
compounds 21 and 23 was then achieved using EDCI and HOBt to provide tetrapeptide $\mathbf{5}$ in $96 \%$ yield.

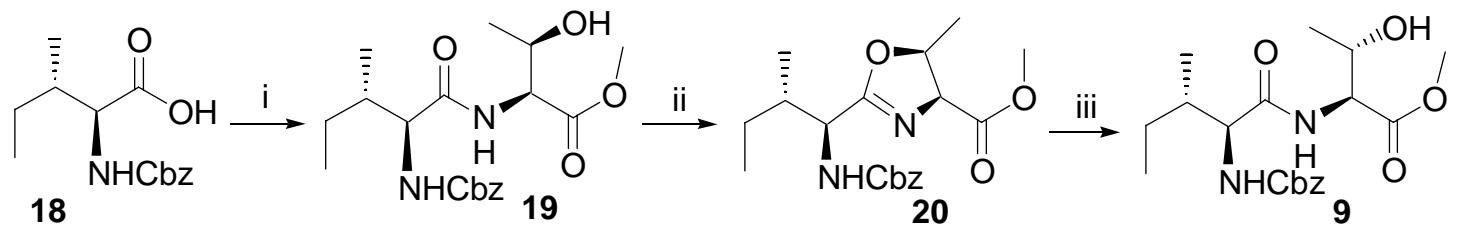
18 $\mathrm{NHCbz} 19$ 20<smiles>[Z12][C@H](C)[C@@H](NC(=O)[C@@H](N)[C@H](C)CC)[C@@H](C)OC</smiles>

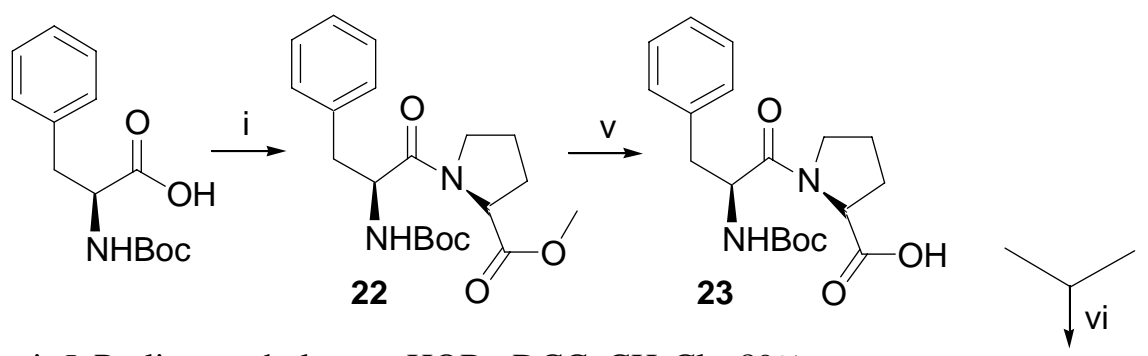

i: L-Proline methyl ester, $\mathrm{HOBt}$, DCC, $\mathrm{CH}_{2} \mathrm{Cl}_{2}$, 89\%;

ii: Burgess's reagent, THF, $70^{\circ} \mathrm{C}, 78 \%$; iii: (a) $0.3 \mathrm{~N}$ HCl, THF; (b) $\mathrm{K}_{2} \mathrm{CO}_{3}, \mathrm{pH}=9.5,85 \%$; iv: $\mathrm{Pd} / \mathrm{C}, \mathrm{H}_{2}$, Methanol, 100\%; v: $\mathrm{LiOH}, \mathrm{THF} / \mathrm{H}_{2} \mathrm{O}, 98 \%$; vi: EDCI, $\mathrm{HOBt}, \mathrm{NMM}, \mathrm{CH}_{2} \mathrm{Cl}_{2}, 96 \%$

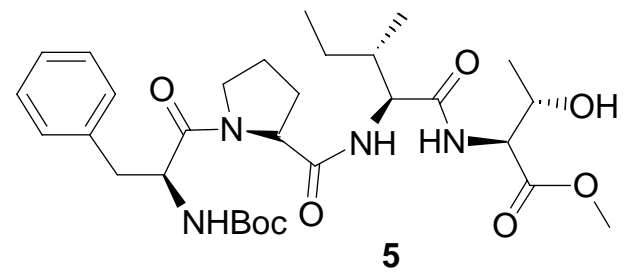

\section{Scheme 3}

With tetrapeptide 5 and tripeptide $\mathbf{6}$ in hand, we have explored two complementary routes for the assembly of linear heptapeptides (4a and $\mathbf{4 b}$ ) to the macrocycle $\mathbf{3}$ (Scheme $\mathbf{4}$ ). After conversion of tripeptide $\mathbf{6}$ into its trifluoacetate salt $\mathbf{2 4}$ and tetrapeptide $\mathbf{5}$ into the corresponding carboxylic acid 25, coupling of these two segments 24 and 25 using EDCI and HOAt was accomplished to give linear peptide $\mathbf{4 a}$ in $90 \%$ yield. ${ }^{12}$ The linear heptapeptide $\mathbf{4 a}$ was then saponified using lithium hydroxide and acidolytic removal of the Boc group followed using TFA/ $\mathrm{CH}_{2} \mathrm{Cl}_{2}$ to provide the linear precursor. Macrocyclization with HATU in DMF under dilute conditions afforded the cyclopeptide 3 in $46 \%$ overall yield as a mixture of two conformational isomers (ratio: $\mathbf{3 a}: \mathbf{3} \mathbf{b}=1: 1.3)^{13}$ An alternative route towards the synthesis of cyclopeptide $\mathbf{3}$ from linear heptapeptide $\mathbf{4 b}$ was also investigated (Scheme 4). Thus, segment condensation of the acid derived from tripeptide $\mathbf{6}$ and the corresponding amine derived from tetrapeptide $\mathbf{5}$ provided linear heptapeptide $\mathbf{4 b}$ in excellent yield. Removal of the methyl ester functionality by lithium hydroxide, and the Teoc protective group by TFA in $\mathbf{4 b}$, gave the corresponding linear precursor which was then cyclized with FDPP $^{14}$ in DMF under dilute conditions to yield cyclopeptide 3 in poor yield (10\%). Interestingly, the ratio of both conformational isomers (3a:3b) derived from this macrolactamization reaction was same as that obtained from the cyclization of heptapeptide 4a. Furthermore, no improvements were achieved by employing other macrocyclization reagents 
such as HBTU ${ }^{15}$ or PyBOP. ${ }^{16}$ Macrocyclization of precursor 4a proceeded in more than twice the yield as obtained for the cyclization of precursoe $\mathbf{4 b}$. Obviously, cyclization depends on the propensity of the linear precursor to adopt a conformation similar to the transition state required for cyclization. ${ }^{18}$ Therefore the yield of the macrocyclization step might vary dramatically with respect to the cyclization precursors.
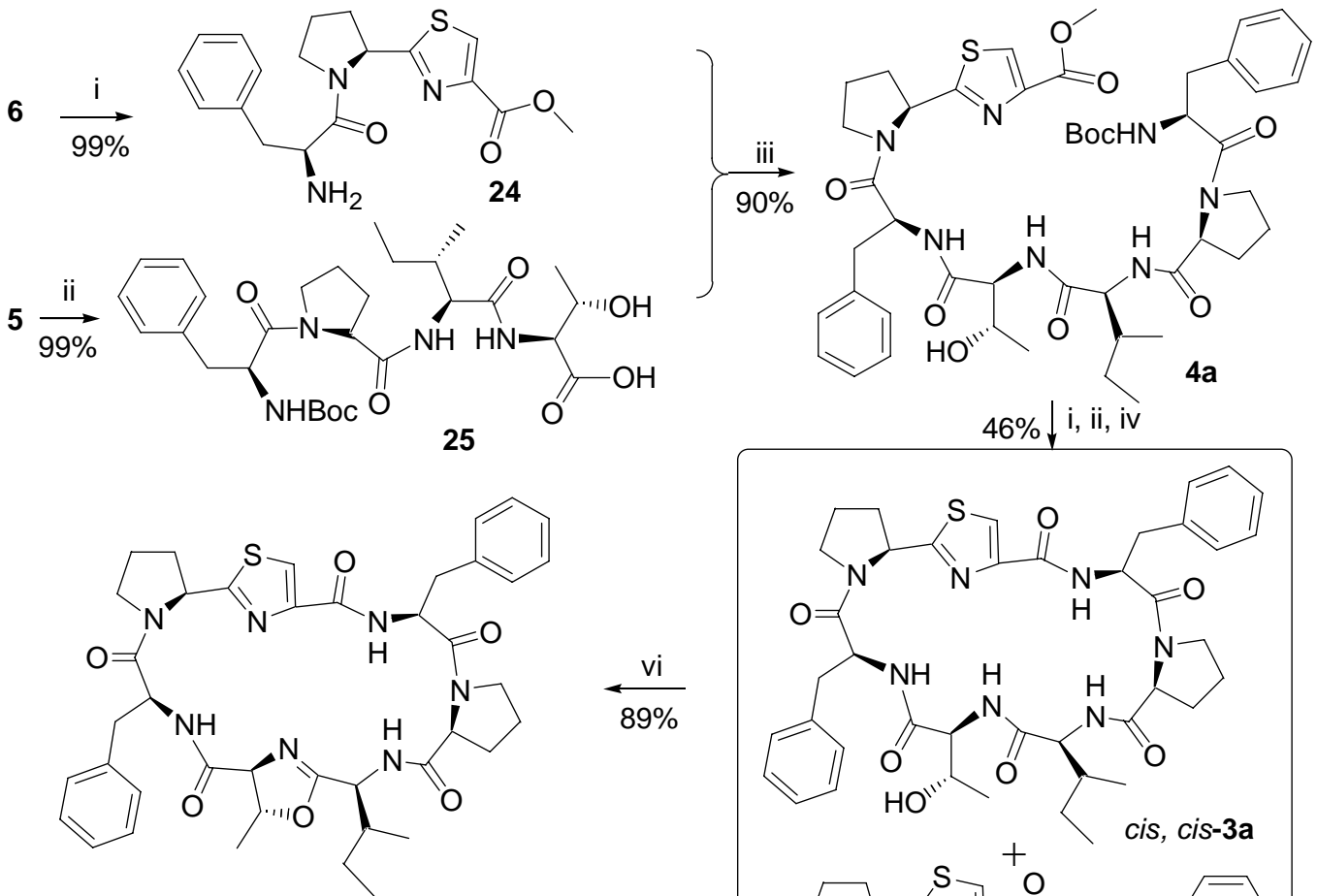

cis, cis ceratospongamide $\mathbf{1}$

i: TFA, $\mathrm{CH}_{2} \mathrm{Cl}_{2}$; ii: $\mathrm{LiOH}, \mathrm{MeOH} / \mathrm{THF} /$ $\mathrm{H}_{2} \mathrm{O}$; iii, EDCI, HOAt, NMM, THF; iv: HATU, DMF; v: FDPP, DIPEA, DMF, v: Deoxo-flour, $\mathrm{CH}_{2} \mathrm{Cl}_{2}$
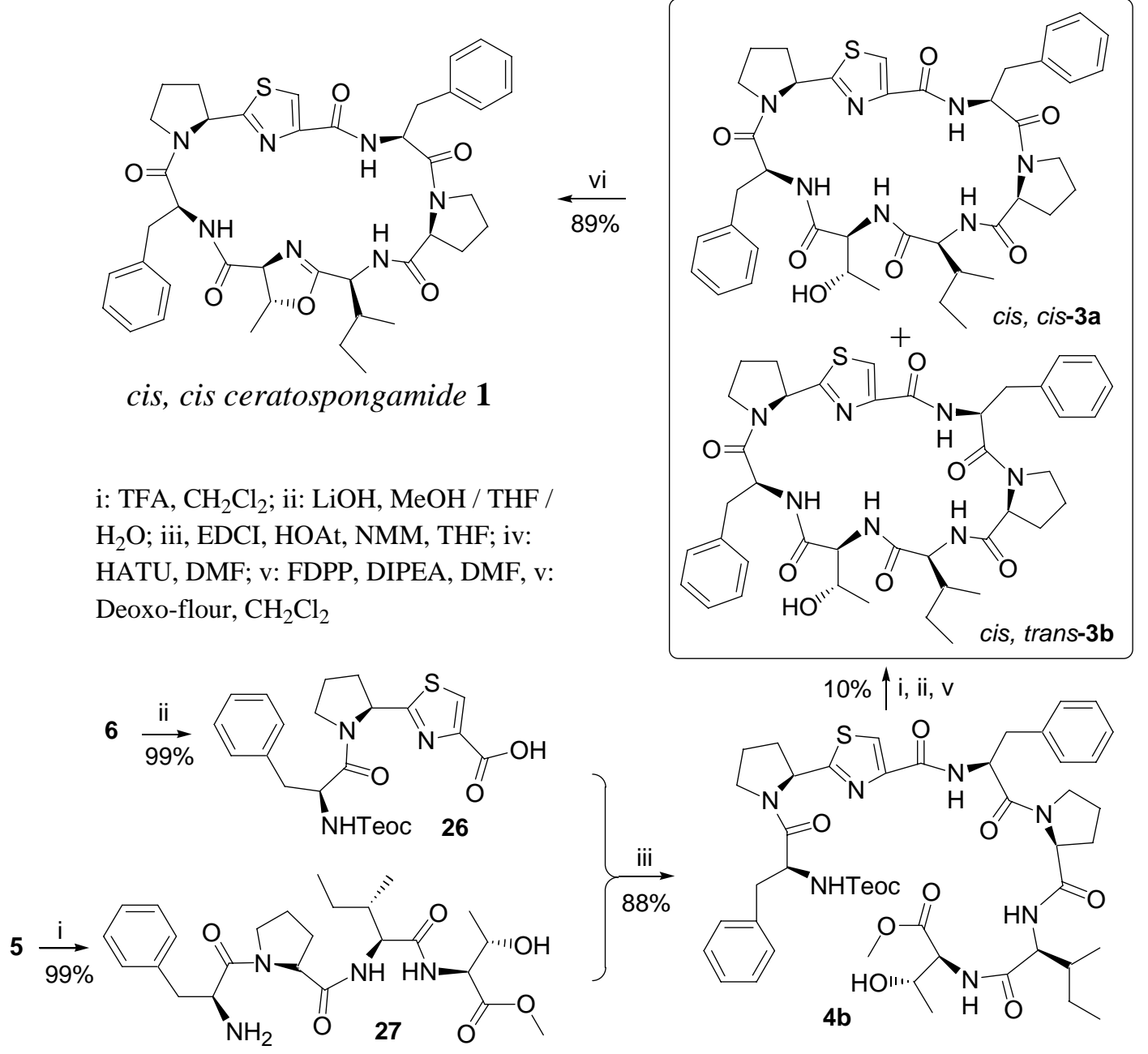

\section{Scheme 4}


Finally, treatment of the pivotal penultimate cyclopeptide 3 with Deoxo-Flour ${ }^{17}$ resulted in facile cyclodehydration to the oxazoline ring producing cis, cis-ceratospongamide structure $\mathbf{1}$ in 89\% yield. This indicates the oxazoline formation is the conformer-determining step. The rigidity of the oxazoline ring presents in the macrocycle can enhance conformational stability (vide infra). The synthetic cyclopeptide showed ${ }^{1} \mathrm{H}$ and ${ }^{13} \mathrm{C}$ NMR spectra which were superimposable on those recorded for naturally derived cis, cis-ceratospongamide $\mathbf{1}$.

In order to understand why the cyclodehydration of the mixture of two conformational isomers (3a and $\mathbf{3 b}$ ) produced cis, cis-ceratospongamide 1, we decided to detect the exact conformation of both isomers $\mathbf{3 a}$ and $\mathbf{3 b}$. Extensive one- and two-dimensional NMR studies on the conformation of cyclopeptide $\mathbf{3}$ in chloroform indicated that there are two major conformational isomers (3a and $\mathbf{3 b}$ ) present in the solution. The detailed NMR data, obtained from C-H COSY, H-H COSY, HMBC and ROESY experiments, allow us to assign the exact chemical shift of both conformational isomers $\mathbf{3 a}$ and $\mathbf{3 b}$. The ratio of these two conformational isomers (3a:3b=1:1.3) was determined by integration of the $\mathrm{NH}$ proton of Phe-1 residue of each conformational isomer. It is known that the cis/trans conformational difference of the proline amide bonds correlates with differential values between proline $\beta$ and $\gamma$ carbons $\left(\Delta \delta_{\beta \gamma}\right)$.A characteristic feature of the cis X-Pro system is the large difference in chemical shift between the $\beta$ and $\gamma$ carbons $(>8 \mathrm{ppm})$ compared to the corresponding trans X-Pro isomers, where the difference is less $(<6 \mathrm{ppm}) .{ }^{19}$ As can be seen from the Table 1, in conformational isomer $3 \mathbf{a}, \Delta \delta_{\beta \gamma}$ of Pro-2 and Pro-1 are 12.8 and 9.4 ppm, respectively. Hence, both proline amides in 3a are cis. On the other hand, in conformational isomer $\mathbf{3 b}, \Delta \delta_{\beta \gamma}$ of Pro-2 and Pro-1 are 11.8 and 3.8 ppm, respectively. This indicated that the proline amides in $\mathbf{3 b}$ are cis (Pro-2) and trans (Pro-1), respectively. These conformational assignments are further supported from the ROESY spectroscopic data (Figure 2), which showed a strong correlation between the $\alpha$-protons of Pro2/Phe-1 as well as Pro-1/Phe-2 in conformational isomer 3a. This is in agreement with the conclusion that $\mathbf{3 a}$ is the cis, cis- isomer. On the other hand, the ROESY data showed a strong correlation between the $\alpha$-protons of the Pro-2/Phe-1, but no such correlations between the $\alpha$ protons of the Pro-1/Phe-2 in conformational isomer $\mathbf{3 b}$. Therefore, $\mathbf{3 b}$ appears to be the cis, trans-isomer. 
Table 1. ${ }^{13} \mathrm{C}$ NMR spectral data (in ppm) for proline carbon and alpha carbons of amino acid residue of cyclopeptide $\mathbf{3 a}$ and $\mathbf{3 b}$

\begin{tabular}{lccccccccccccccc}
\hline \multicolumn{1}{c}{ A. A. } & \multicolumn{4}{c}{ Pro-1 } & \multicolumn{4}{c}{ Pro-2 } & \multicolumn{1}{c}{ Ile } & \multicolumn{2}{c}{ Thr } & Phe-1 & Phe-2 \\
\hline position & $\mathrm{C} \alpha$ & $\mathrm{C} \beta$ & $\mathrm{C} \gamma$ & $\mathrm{C} \delta$ & $\mathrm{C} \alpha$ & $\mathrm{C} \beta$ & $\mathrm{C} \gamma$ & $\mathrm{C} \delta$ & $\mathrm{C} \alpha$ & $\mathrm{C} \alpha$ & $\mathrm{C} \beta$ & $\mathrm{C} \alpha$ & $\mathrm{C} \alpha$ \\
cis,cis 3a & 61.5 & 31.3 & 21.9 & 47.4 & 58.1 & 34.0 & 21.2 & 46.0 & 59.0 & 59.9 & 70.4 & 53.8 & 54.8 \\
cis,trans 3b & 62.9 & 29.7 & 25.9 & 46.5 & 58.8 & 34.1 & 22.3 & 45.7 & 57.4 & 56.5 & 66.3 & 53.4 & 52.9 \\
\hline
\end{tabular}

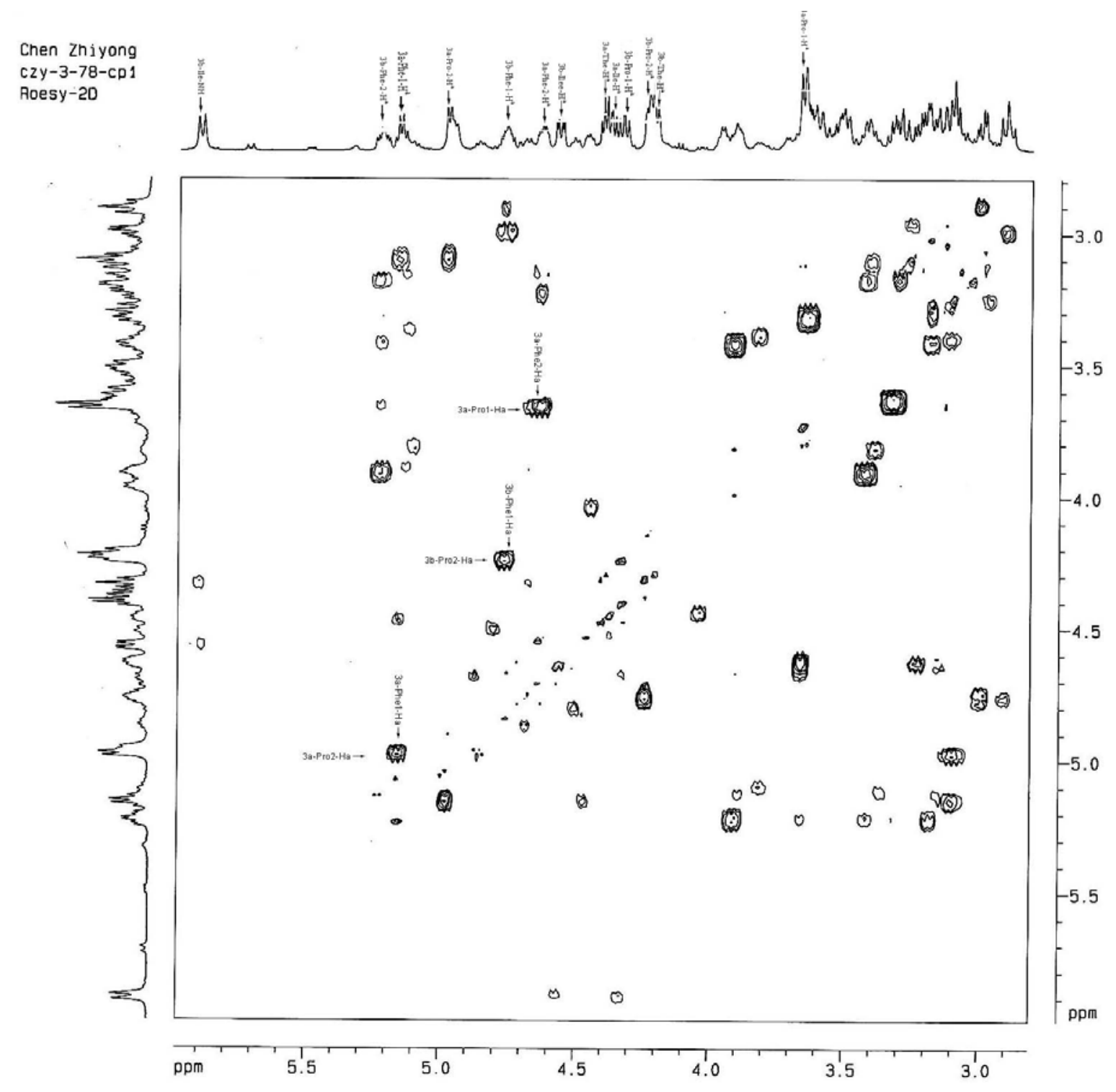

Figure 2. ROESY spectrum $\left(\mathrm{CDCl}_{3}, 500 \mathrm{MHz}\right)$ of cyclopeptides $\mathbf{3 a}$ and $\mathbf{3 b}$. 
Since the cyclization of both linear peptides $\mathbf{4 a}$ and $\mathbf{4 b}$ produced cyclopeptide $\mathbf{3}$ with the same ratio of conformational isomers ( $\mathbf{3 a} \& \mathbf{3} \mathbf{b}$ ), this suggests that there is an inter-conversion between both conformational isomers $\mathbf{3 a}$ and $\mathbf{3 b}$. This result is in accord with those obtained by the Deng and Taunton, ${ }^{4 a}$ who observed that conformer interconversion of cyclopeptide 3 occurs at room temperature. ${ }^{20}$ Cyclodehydration of cyclopeptide 3 produced cis, cis ceratospongamide in excellent yield deserves further comments. Although the aforementioned NMR studies indicated there are two conformational isomers (3a \& $\mathbf{3 b}$ ) present in solution, the cis, cis ceratospongamide was derived from the corresponding cis, cis conformational isomer 3a. Since the conformer interconversion occurs at room temperature, conformational isomer $\mathbf{3 b}$ must equilibrate to the corresponding isomer 3a prior to taking part in the oxazoline formation process. Furthermore, the cyclodehydration reagent used for the oxazoline formation may interrupt the hydrogen bond associated with the Phe- 2 in conformational isomer $3 \mathbf{b}$, which would also facilitate the intramolecular trans/cis isomerization process.

\section{Conclusions}

A total synthesis of cis, cis-ceratospongamide 1 was accomplished via [4+3] fragment condensation, macrolactamization and subsequent cyclodehydration. Our results indicated that the yield of the macrocyclization step varied dramatically with respect to the cyclization precursors. Extensive NMR studies on cyclopeptide $\mathbf{3}$ revealed that there are two major conformational isomers present in the solution and the conformer interconversion facilitated the formation of cis, cis-ceratospongamide.

\section{Experimental Section}

General Procedures. All starting material and reagents were obtained from commercial sources and were used without further purification. Solvents were dried by distillation from sodium benzophenone ketyl (THF, Et $2 \mathrm{O}$ ) or $\mathrm{CaH}_{2}\left(\mathrm{CH}_{2} \mathrm{Cl}_{2}\right)$ under $\mathrm{N}_{2}$. Air- and/or moisture-sensitive reactions were performed in oven-dried $\left(110^{\circ} \mathrm{C}\right)$ glassware under $\mathrm{N}_{2}$. TLC was carried out on E. Merck pre-coated silica gel $60 \mathrm{GF}_{254}$ plates. Chromatography refers to flash chromatography on 230-400-mesh silica gel. Melting points are uncorrected. Specific rotations were measured with a Perkin Elmer 341 polarimeter at ambient temperature using $0.9998 \mathrm{dm}$ cell with $1 \mathrm{ml}$ capacity. Infrared (IR) spectra were recorded with a Nicolet 5DXB FT-IR spectrometer. ${ }^{1} \mathrm{H}$ NMR and ${ }^{13} \mathrm{C}$ NMR spectra were recorded using either Bruker AC-300 MHz or Bruker AC-500MHz in $\mathrm{CDCl}_{3}$ solution with tetramethylsilane as an internal standard. Electron impact (EI) mass spectra (HRMS and MS) were obtained with a Finnegan MAT 95. 
$N$-Boc-L-Pro-L-Serine methyl ester (12). To a solution of $N$-Boc-L-proline (6.46 g, $30 \mathrm{mmol}$ ), L-serine methyl ester hydrochloride $(4.68 \mathrm{~g}, 30 \mathrm{mmol})$ in dichloromethane $(200 \mathrm{~mL})$ at $0^{\circ} \mathrm{C}$, HOBt (6.05 g, $47 \mathrm{mmol})$, DCC (9.28 g, $45 \mathrm{mmol})$ and triethylamine (8.5 mL, $61 \mathrm{mmol})$ were added. The reaction mixture was stirred for $1 \mathrm{~h}$ at $0^{\circ} \mathrm{C}$ and 12 hours at room temperature, during which time a white precipitate formed. This mixture was filtered; the filtrate was diluted with dichloromethane $(300 \mathrm{~mL})$, washed with saturated sodium hydrogen carbonate $(100 \mathrm{~mL})$, ammonium chloride $(100 \mathrm{~mL})$, brine $(60 \mathrm{~mL})$ and dried over sodium sulfate. The solvent was then evaporated and the residue was purified by flash on silica gel to give the dipeptide 12 (8.43 g, 89\% yield). ${ }^{1} \mathrm{H}$ NMR $\left(\mathrm{CDCl}_{3}\right.$ ) (multiple rotamers): $\delta 1.44(9 \mathrm{H}, \mathrm{s}) ; 1.85 \sim 2.35$ (4H, m); 3.70 3.43 (4H, m); 3.82(3H, s); $4.71(1 \mathrm{H}, \mathrm{m}) ; 5.15(1 \mathrm{H}, \mathrm{m}) ;{ }^{13} \mathrm{C} \mathrm{NMR}\left(\mathrm{CDCl}_{3}\right)$ (multiple rotamers): $\delta$ 24.6; 28.3; 29.1; 47.1; 55.2; 52.1; 60.3; 62.3; 80.7; 155.3; 170.7; 172.5; IR (cm $\left.{ }^{-1}\right)$ : 3418, 2977, 1747, 1681. EIMS: 316, 286, 260, 243, 215, 171, 156, 137; HRMS (EI): calcd for $\mathrm{C}_{14} \mathrm{H}_{24} \mathrm{~N}_{2} \mathrm{O}_{6}$ 316.1634, found 316.1623.

$\boldsymbol{N}$-Boc-L-Pro-L-(OTBS)-Ser methyl ester (13). To the solution of dipeptide 12 (8.10 g, $25.633 \mathrm{mmol}$ ) and TBS-Cl (4.44 g, $29.2 \mathrm{mmol})$ in dichloromethane (30 mL), DMAP (0.336 g, $2.254 \mathrm{mmol})$ and triethylamine $(4.2 \mathrm{ml}, 30 \mathrm{mmol})$ were added at $0^{\circ} \mathrm{C}$. The solution was stirred at room temperature for 24 hours, then diluted with dichloromethane (200 $\mathrm{mL}$ ), washed with saturated sodium hydrogen carbonate $(60 \mathrm{~mL})$, ammonium chloride $(60 \mathrm{~mL})$, brine $(60 \mathrm{~mL})$, and dried over sodium sulfate. The organic solvent was evaporated and the residue was purified by flash chromatography on silica gel to give the title compound $13\left(10.15 \mathrm{~g}, 95 \%\right.$ yield). $[\alpha]_{\mathrm{D}}{ }^{20}{ }_{-}$ 2.78 (c 3.47, $\left.\mathrm{CHCl}_{3}\right) ;{ }^{1} \mathrm{H} \mathrm{NMR}\left(\mathrm{CDCl}_{3}\right.$ ) (multiple rotamers): $\delta-0.27(6 \mathrm{H}, \mathrm{s}) ; 0.82$ (9H, s) 1.42 (9H, s); 2.28 1.80 (4H, m); 3.47(2H, m); 3.74 (3H, s); 4.12 3.99; 4.7250(1H, m); 5.22(1H, m); 6.84\&7.31(1H, br); ${ }^{13} \mathrm{C}$ NMR $\left(\mathrm{CDCl}_{3}\right)$ (multiple rotamers): $\delta-6.1 ;-6.0 ; 17.7 ; 23.2 ; 25.2 ; 27.9$; 30.6; 46.6; 59.8; 51.8; 53.8; 63.2; 79.9; 154.1; 170.0; 172.0; IR $\left(\mathrm{cm}^{-1}\right)$ : 3418, 2878, 1747, 1680, 1519; EIMS: 430, 398, 386, 371, 330, 315, 317, 293, 273, 253, 114, 119, 170; HRMS (EI): calcd for $\mathrm{C}_{20} \mathrm{H}_{38} \mathrm{~N}_{2} \mathrm{O}_{6} \mathrm{Si} 430.2499$, found 430.2499.

$\boldsymbol{N}$-Boc-L-Pro(C=S)-L-(OTBS)-Ser methyl ester (14). To compound 13 (4.76 g, 11.423 mmol) in benzene $(30 \mathrm{~mL})$, a solution of Lawesson's reagent in benzene $(30 \mathrm{~mL})$ was added. After the reaction mixture was under refluxed for 6 hours, the solvent was evaporated and the residue was purified by flash chromatography on silica gel to give the title compound $\mathbf{1 4}$ ( $3.21 \mathrm{~g}, 65 \%$ yield). $[\alpha]_{\mathrm{D}}{ }^{20}-7.12$ (c 41, $\left.\mathrm{CHCl}_{3}\right) ;{ }^{1} \mathrm{H}$ NMR $\left(\mathrm{CDCl}_{3}\right)$ (multiple rotamers): $\delta$-0.54(6H, s); 0.90(9H, m); 1.49(9H, m); 1.88(2H, m); 2.36(2H, m); 3.53(2H, m); 3.81(3H, s); 4.11(2H, m); 4.78(1H, m); 5.28(1H, m); 8.53(1H, br); ${ }^{13} \mathrm{C}$ NMR $\left(\mathrm{CDCl}_{3}\right)$ (multiple rotamers): $\delta$-5.9; -5.7; 14.1; 17.894; 20.9; 25.5.28.1; 47.4; 52.4; 59.0; 60.2; 62.3; 80.6; 154.8; 170.9; 203.8. IR (cm $\left.{ }^{-1}\right): 2977,2935$, 2885, 1741, 1680, 1519, 1250, 1165; EIMS: 446, 389, 386, 321, 344, 333, 330, 315, 293, 289, 258, 214, 153, 136, 114; HRMS (EI): calcd for $\mathrm{C}_{20} \mathrm{H}_{38} \mathrm{~N}_{2} \mathrm{O}_{5} \mathrm{SSi} 446.2271$, found 446.2277.

$\boldsymbol{N}$-Boc-L-Pro(C=S)-L-Ser methyl ester (15). To compound 14 (4.31 g, $9.95 \mathrm{mmol}$ ) in THF (20 mL), TBAF (10 mL, $1 \mathrm{M}$ in THF) was added. The solution was stirred for 12 hours and then diluted with ethyl acetate (100 mL), washed with ammonium chloride (2 x $20 \mathrm{~mL})$, brine $(20 \mathrm{~mL})$ and dried over sodium sulfate. The solvent was evaporated and the residue was purified 
by flash chromatography on silica gel to give the title compound 15 (3.12 g, 99\% yield). [ $\alpha]_{D}{ }^{20}$ 14.16 (c1.25, $\left.\mathrm{CHCl}_{3}\right) .{ }^{1} \mathrm{H} \mathrm{NMR}\left(\mathrm{CDCl}_{3}\right)$ (multiple rotamers): $\delta 1.42(9 \mathrm{H}, \mathrm{s}) ; 3.40 \sim 3.68(4 \mathrm{H}, \mathrm{m})$; 2.30 1.86(4H, m); 5.10 5.16(1H, m); 4.67 4.77(1H, m); 3.80(3H, m); ${ }^{13} \mathrm{C} \mathrm{NMR}\left(\mathrm{CDCl}_{3}\right)$ (multiple rotamers): $\delta$ 22.6; 28.1; 25.0; 47.4; 52.6; 59.6; 61.0; 67.1; 80.6; 154.9; 169.9; 205.2; IR $\left(\mathrm{cm}^{-1}\right)$ : 3347, 2975, 1744, 1676, 1425, 1162. EIMS: 332, 259, 258, 215, 197, 231, 214, 170, 153, 142, 142, 136, 114. HRMS (EI): calcd for $\mathrm{C}_{14} \mathrm{H}_{24} \mathrm{~N}_{2} \mathrm{O}_{5} \mathrm{~S}$ 332.1406, found 332.1404.

$\boldsymbol{N}$-Boc-L-Pro-Thiazoline methyl ester (16). To compound 15 (2.5 g, $7.53 \mathrm{mmol}$ ) in THF $(10 \mathrm{~mL})$ a solution of Burgess' reagent $(2.1 \mathrm{~g}, 8.76 \mathrm{mmol})$ in THF (30 mL) was added. The solution was heated under reflux for 4 hours, and then concentrated. The residue was purified by flash chromatography on silica gel to give thiazoline 16 (2.17 g, 85\% yield). [ $\alpha]_{\mathrm{D}}{ }^{20}-3.99$ (c 4.56, $\left.\mathrm{CHCl}_{3}\right) ;{ }^{1} \mathrm{H}$ NMR $\left(\mathrm{CDCl}_{3}\right)$ (multiple rotamers): $\delta$ 1.42(9H, s); 1.83 2.30(4H, m); 3.39 3.67(4H, $\mathrm{m}) ; 3.80(3 \mathrm{H}, \mathrm{m}) ; 4.67(1 \mathrm{H}, \mathrm{m}) ; 5.12(1 \mathrm{H}, \mathrm{m}) ;{ }^{13} \mathrm{C} \mathrm{NMR}\left(\mathrm{CDCl}_{3}\right)$ (multiple rotamers): $\delta$ 23.8; 28.2; 32.6; 34.2; 46.6; 52.61\&52.9; 67.6; 78.4; 80.1; 154.037; 170.9; 179.8\&179.7; IR(cm $\left.{ }^{-1}\right): 1710$, 1640, 1456, 1206, 1141.

$\boldsymbol{N}$-Boc-L-prolyl-thiazole methyl ester (8). To compound 16 (1.2 g, $3.82 \mathrm{mmol})$ in dichloromethane $(10 \mathrm{~mL})$, a solution of activated manganese dioxide $(2.1 \mathrm{~g}, 24 \mathrm{mmol})$ in dichloromethane $(30 \mathrm{~mL})$ was added. The reaction was monitored by tlc until the starting material was consumed. The reaction mixture was then cooled to room temperature and the excess manganese dioxide was filtered. The solution was concentrated and the residue was purified by flash chromatography on silica gel to give thiazole 8 (1.17 g, 95\% yield). [ $\alpha]_{\mathrm{D}}{ }^{20}{ }_{-}$ 91.78 (с 2.47, $\left.\mathrm{CHCl}_{3}\right) ; 1 \mathrm{H} \mathrm{NMR}\left(\mathrm{CDCl}_{3}\right)$ (multiple rotamers): $\delta 1.33 \& 1.49(9 \mathrm{H}, \mathrm{s}) ; 1.96(2 \mathrm{H}, \mathrm{m})$; $2.24(2 \mathrm{H}, \mathrm{m}) ; 3.63(2 \mathrm{H}, \mathrm{m}) ; 3.96(3 \mathrm{H}, \mathrm{s}) ; 8.11(1 \mathrm{H}, \mathrm{s}) ; 13 \mathrm{C} \mathrm{NMR}\left(\mathrm{CDCl}_{3}\right)$ (multiple rotamers): $\delta$ 23.023.7; 28.1; 32.8\&34.1; 46.9\&46.6; 52.3; 59.5\&59.0; 80.3; 126.9; 146.6; 154.0; 161.7; 177.1; IR (cm $\left.{ }^{-1}\right)$ : 2953, 1716, 1644, 1247, 1432, 860, 837; EIMS: 312, 281, 256, 170, 212, 153, 136, 195, 183, 157; HRMS (EI): calcd for $\mathrm{C}_{14} \mathrm{H}_{20} \mathrm{~N}_{2} \mathrm{O}_{4} \mathrm{~S}$ 312.1144, found 312.1149

$\boldsymbol{N}$-Teoc-L-Phe- L-Pro-Thz methyl ester (6). Thiazole 8 (210 mg, $0.663 \mathrm{mmol}$ ) was dissolved in 1:1 TFA/ $\mathrm{CH}_{2} \mathrm{Cl}_{2}(2 \mathrm{~mL})$ at $0^{\circ} \mathrm{C}$. The solution was stirred at room temperature for 2 hours. The solvent was removed under reduced pressure and the residue was redissolved in $\mathrm{CH}_{2} \mathrm{Cl}_{2}$ and reconcentrated repeatedly to remove excess TFA. The dry sample was stored under high vacuum to give the TFA salt which was used without further purification. This salt was combined with LTeoc-phenylalanine (307 mg, $1 \mathrm{mmol})$ in THF $(10 \mathrm{~mL})$ at $0^{\circ} \mathrm{C}$, and $\mathrm{HOBt}(188 \mathrm{mg}, 1.38 \mathrm{mmol})$, EDCI (250 mg, $1.3 \mathrm{mmol})$ and NMM (0.73 ml, $6.6 \mathrm{mmol})$ were added. The reaction mixture was stirred at $0^{\circ} \mathrm{C}$ for 1 hour and then at room temperature for 22 hours. Removal of the solvent in vacuo followed by chromatography on silica gel afforded the title compound 6 (317 mg, 84\% yield). $[\alpha]_{\mathrm{D}}{ }^{20}-73.36$ (c 2.32, $\mathrm{CHCl}_{3}$ ); ${ }^{1} \mathrm{H} \mathrm{NMR}\left(\mathrm{CDCl}_{3}\right)$ (multiple rotamers): $\delta$-0.01(9H, s); $0.87 \sim 0.94(2 \mathrm{H}, \mathrm{m}) ; 1.92 \sim 2.02(2 \mathrm{H}, \mathrm{m}) ; 2.15 \sim 2.25 \& 2.36 \sim 2.39(2 \mathrm{H}, \mathrm{m}) ; 2.88 \sim 3.07(2 \mathrm{H}, \mathrm{m})$; 3.31 3.37(1H, m)\&3.64 3.77(1H, m); 3.90(3H, s); 3.99 4.11(2H, m); 4.41 4.43(1H, d, J=6.6 $\mathrm{Hz}) \& 4.71 \sim 4.75\left(1 \mathrm{H}, \mathrm{q}, \mathrm{J}_{1}=7.4 \mathrm{~Hz}, \mathrm{~J}_{2}=15.4 \mathrm{~Hz}\right) ; 5.42 \sim 5.51(1 \mathrm{H}, \mathrm{m}) ; 7.12 \sim 7.28(5 \mathrm{H}, \mathrm{m}) ; 8.03$ \&8.02(1H, s); ${ }^{13} \mathrm{C} \mathrm{NMR}\left(\mathrm{CDCl}_{3}\right)$ (multiple rotamers): $\delta-1.1 ; 17.7 ; 24.5 ; 31.6 ; 36.9 ; 45.6 ; 47.1$; 52.4; 54.5; 58.6; 62.3; 126.8; 128.5; 129.4; 129.7; 137.9; 156.6; 161.6; 171.4; 173.8; IR (cm $\left.{ }^{-1}\right)$ : 
3431, 3020; 1712; 1648, 1506; EIMS: 503, 412, 343, 342, 309, 307, 251, 240, 195, 170; HRMS(EI): calcd for $\mathrm{C}_{24} \mathrm{H}_{33} \mathrm{~N}_{3} \mathrm{O}_{5} \mathrm{SSi}$ 503.1910, found 503.1906.

$N$-Cbz-L-Ile-L-Thr methyl ester (19). $N$-Cbz-L-isoleucine (13.3 g, $50 \mathrm{mmol}$ ), L-threonine methyl ester hydrochloride (6.7 g, $50 \mathrm{mmol})$ and HOBt $(10.2 \mathrm{~g}, 75 \mathrm{mmol})$ were dissolved into dichloromethane $(200 \mathrm{~mL})$ at $0^{\circ} \mathrm{C}$. To this solution, DCC $(15.5 \mathrm{~g}, 75 \mathrm{mmol})$, triethylamine $(14 \mathrm{~mL}, 100 \mathrm{mmol})$ were added at $0^{\circ} \mathrm{C}$. The solution was stirred at $0^{\circ} \mathrm{C}$ for 1 hour, then at room temperature for 12 hours. The solid dicyclohexylurea was removed by filtration and washed with dichloromethane $(2 \times 20 \mathrm{~mL})$. The filtrate was diluted with dichloromethane (300 mL), washed with saturated sodium hydrogen carbonate $(100 \mathrm{~mL})$, ammonium chloride $(100 \mathrm{~mL})$, brine $(60 \mathrm{~mL})$ and dried over sodium sulfate. Removal of the solvent in vacuo followed by chromatography on silica gel afforded the title compound 19 (6.77 g, 89\% yield). ${ }^{1} \mathrm{H}$ NMR $\left(\mathrm{CDCl}_{3}\right)$ (multiple rotamers): $\delta$ 0.89(3H, t, J=7.3 Hz); 0.96(3H, d, J=6.7 Hz); 1.16(3H, t, J=6.4 $\mathrm{Hz}) ; 1.56 \& 1.16(2 \mathrm{H}, \mathrm{m}) ; 1.85(1 \mathrm{H}, \mathrm{m}) ; 3.74(3 \mathrm{H}, \mathrm{s}) ; 4.13(1 \mathrm{H}, \mathrm{t}, \mathrm{J}=8.1 \mathrm{~Hz}) ; 4.33(1 \mathrm{H}, \mathrm{m}) ; 4.61(1 \mathrm{H}$, dd, $\left.\mathrm{J}_{1}=2.3 \mathrm{~Hz}, \mathrm{~J}_{2}=8.9 \mathrm{~Hz}\right) ; 5.08\left(2 \mathrm{H}, q, \mathrm{~J}_{1}=12.2 \mathrm{~Hz}, \mathrm{~J}_{2}=17.9 \mathrm{~Hz}\right) ; 5.62(1 \mathrm{H}, \mathrm{d}, \mathrm{J}=8.8 \mathrm{~Hz}) ;$ 7.05 7.35(5H, m); 7.05(1H, d, J=8.7 Hz); ${ }^{13} \mathrm{C}$ NMR ( $\mathrm{CDCl}_{3}$ ) (multiple rotamers): $\delta$ 11.2; 15.2; 19.8; 24.7; 37.332; 52.6; 56.5; 57.3; 59.7; 67.022; 68.0; 128.5; 127.9; 128.1; 136.2; 171.2; 172.1; IR $\left(\mathrm{cm}^{-1}\right)$ : 3347, 3021, 2965, 1785, 1717, 1660, 1455, 754; EIMS: 380, 336, 220, 176, 172, 190 , 136, 153, 108; HRMS(EI): calcd for $\mathrm{C}_{19} \mathrm{H}_{28} \mathrm{~N}_{2} \mathrm{O}_{6} 380.1947$, found 380.1937.

$\boldsymbol{N}$-Cbz-L-Ile-L-aThr methyl ester (9). To dipeptide 19 (783 mg, $2.06 \mathrm{mmol}$ ) in THF (10 mL), a solution of Burgess' reagent $(530 \mathrm{mg}, 2.3 \mathrm{mmol})$ in THF $(10 \mathrm{~mL})$ was added at room temperature. The solution was stirred at $70^{\circ} \mathrm{C}$ for 3 hours and cooled to room temperature. The solvent was evaporated and the residue was purified by flash chromatography on silica gel to give oxazoline (20) (582 mg, 78\% yield). ${ }^{1} \mathrm{H}$ NMR: $\left(\mathrm{CDCl}_{3}\right) \delta 0.98(3 \mathrm{H}, \mathrm{t}, \mathrm{J}=7.3 \mathrm{~Hz}) ; 1.04(3 \mathrm{H}, \mathrm{d}$, $\mathrm{J}=6.8 \mathrm{~Hz}) ; 1.33(3 \mathrm{H}, \mathrm{d}, \mathrm{J}=6.4 \mathrm{~Hz}) ; 1.61 \& 1.21(2 \mathrm{H}, \mathrm{m}) ; 1.99 \sim 1.91(1 \mathrm{H}, \mathrm{m}) ; 3.78(3 \mathrm{H}, \mathrm{m}) ; 4.47(1 \mathrm{H}$, q, $\left.\mathrm{J}_{1}=4.5 \mathrm{~Hz}, \mathrm{~J}_{2}=8.2 \mathrm{~Hz}\right) ; 4.84(1 \mathrm{H}, \mathrm{d}, \mathrm{J}=10.2 \mathrm{~Hz}) ; 4.96(1 \mathrm{H}, \mathrm{m}) ; 5.14\left(2 \mathrm{H}, \mathrm{q}, \mathrm{J}_{1}=12.2 \mathrm{~Hz}, \mathrm{~J}_{2}=16.2\right.$ $\mathrm{Hz})$; 5.60(1H, d, J=8.9 Hz). 7.40 7.31(5H, m); ${ }^{13} \mathrm{C} \mathrm{NMR:}\left(\mathrm{CDCl}_{3}\right) \delta$ 11.7; 15.0; 16.1; 24.6; 38.3; 52.0. 53.6; 66.8; 70.7; 78.4; 128.4; 128.0; 127.9; 136.3; 156.0; 169.5; 170.0 .

To a solution of oxazoline 20 (543 mg, $1.5 \mathrm{mmol})$ in THF $(10 \mathrm{~mL}), 0.3 \mathrm{~N} \mathrm{HCl}(15 \mathrm{~mL})$ was added dropwise at $0^{\circ} \mathrm{C}$. The solution was stirred at room temperature for 2 hours; the $\mathrm{pH}$ value of reaction solution was then adjusted to 10 with solid potassium carbonate. After stirring for further 2 hours, the solution was neutralized to $\mathrm{pH} 7$ and extracted with ethyl acetate $(3 \mathrm{x}$ $50 \mathrm{~mL})$. The combined organic layer was washed with ammonium chloride $(20 \mathrm{~mL})$, brine $(20 \mathrm{~mL})$ and dried over sodium sulfate. Removal of the solvent in vacuo followed by chromatography on silica gel afforded the title compound 9 (485 mg, 85\% yield). $[\alpha]_{D}{ }^{20}+13.17$ (c 2.52, $\mathrm{CHCl}_{3}$ ); ${ }^{1} \mathrm{H}$ NMR: $\delta$ 0.92(3H, t, J=7.4 Hz); 0.95(3H, d, J=6.8 Hz); 1.17(3H, d, J=6.6 $\mathrm{Hz}) ; 1.58 \& 1.17(2 \mathrm{H}, \mathrm{m}) ; 1.90(1 \mathrm{H}, \mathrm{m}) ; 3.79(3 \mathrm{H}, \mathrm{s}) ; 4.05\left(1 \mathrm{H}, \mathrm{dd}, \mathrm{J}_{1}=6.7 \mathrm{~Hz}, \mathrm{~J}_{2}=8.2 \mathrm{~Hz}\right) ; 4.16(1 \mathrm{H}$, m); 4.64(1H, t, J=4.0 Hz); 5.11(2H, s); 5.29(1H, d, J=7.8 Hz); 5.62(1H, d, J=8.8 Hz), 7.06(1H, d, $\mathrm{J}=7.2 \mathrm{~Hz}) ; 7.35(5 \mathrm{H}, \mathrm{m}) ;{ }^{13} \mathrm{C}$ NMR: $\delta$ 11.2; $15.4 ; 18.8 ; 24.7 ; 37.3 ; 52.5 ; 58.1 ; 60.0 ; 67.6 ; 68.7$; 128.0; 128.5; 128.1; 136.1; 156.5; 170.3; 172.1; IR $\left(\mathrm{cm}^{-1}\right)$ : 3347, 3021, 2965, 1785, 1717, 1660 , 
1455, 754; EIMS: 380, 336, 220, 176, 172, 190, 136, 153, 108; HRMS(EI): calcd for $\mathrm{C}_{19} \mathrm{H}_{28} \mathrm{~N}_{2} \mathrm{O}_{6} 380.1947$, found 380.1937.

$N$-Boc-L-Phe-L-Pro methyl ester (22). $N$-Boc-L-phenylalanine (4.65 g, 17.6 mmol), L-proline methyl ester hydrochloride (2.72 g, $17.6 \mathrm{mmol}$ ) and HOBt (2.4 g, $17.7 \mathrm{mmol})$ were dissolved into dichloromethane $(100 \mathrm{~mL})$ at $0^{\circ} \mathrm{C}$. To this solution, DCC $(4.015 \mathrm{~g}, 19.5 \mathrm{mmol})$ and triethyl amine (5.6 mL, $40 \mathrm{mmol}$ ) were added. The solution was stirred at $0^{\circ} \mathrm{C}$ for 1 hour and then at room temperature for further 12 hours. The solid dicyclohexylurea was removed by filtration and washed with dichloromethane (2 x $20 \mathrm{~mL}$ ). The filtrate was diluted with dichloromethane (300 mL), washed with saturated sodium hydrogen carbonate $(100 \mathrm{~mL})$, ammonium chloride $(100 \mathrm{~mL})$, brine $(60 \mathrm{~mL})$ and dried over sodium sulfate. Removal of the solvent in vacuo followed by chromatography on silica gel afforded the title compound 22 (5.93 g, 89\% yield). ${ }^{1} \mathrm{H}$ NMR $\left(\mathrm{CDCl}_{3}\right)$ (multiple rotamers): $\delta 1.37(9 \mathrm{H}, \mathrm{m}) ; 1.90(2 \mathrm{H}, \mathrm{m}) ; 2.21 \sim 2.13(2 \mathrm{H}, \mathrm{m})$; 2.88 3.12(2H, m): 3.60 3.58\&3.46 3.21(2H, m); 3.70\&3.67 (3H, s); 4.77 4.49(1H, m);

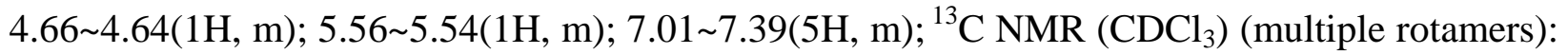
$\delta$ 24.4; 27.8; 28.50; 38.4; 46.3; 51.6; 52.8; 58.4; 78.8; 126.2; 127.8; 129.2; 136.1; 154.7; 170.1; 171.8 .

N-Boc-L-Phe-L-Pro-L-Ile-L-aThr methyl ester (5). $N$-Boc-L-Phe-L-Pro methyl ester (22) (330 mg, $1 \mathrm{mmol}$ ) was dissolved into the solution of lithium hydroxide (220 mg, $5 \mathrm{mmol}$ ) in THF (2 mL), methanol $(2 \mathrm{~mL})$ and $\mathrm{H}_{2} \mathrm{O}(1 \mathrm{~mL})$. The reaction was followed by tlc until the starting material was consumed. The reaction solvent was then neutralized with diluted $\mathrm{HCl}$ solution and extracted with ethyl acetate $(3 \times 30 \mathrm{~mL})$. The combined organic layers was dried and evaporated to give free acid (23) for use in next step with out further purification.

$N$-Cbz-L-Ile-L- $a$ Thr methyl ester (9) $(250 \mathrm{mg}, 0.65 \mathrm{mmol})$ in methanol (10 mL) was added $10 \% \mathrm{Pd} / \mathrm{C}(10 \mathrm{mg})$. Hydrogen $(1 \mathrm{~atm})$ was then applied to the reaction system. The reaction mixture was stirred under hydrogen ( $1 \mathrm{~atm}$ ) for 4 hours and then the $\mathrm{Pd} / \mathrm{C}$ was filtered through a glass wool plug. After removing the solvent under reduced pressure, the residue was combined with acid 23 in THF (20 ml) at $0^{\circ} \mathrm{C}$ and HOBt (135 mg, $1 \mathrm{mmol}$ ), EDCI (260 mg, $\left.1.35 \mathrm{mmol}\right)$ and NMM (0.5 mL, $4.55 \mathrm{mmol})$ were added. The reaction mixture was stirred at $0^{\circ} \mathrm{C}$ for 1 hour and then at room temperature for 22 hours. The solvent was dried $\left(\mathrm{Na}_{2} \mathrm{SO}_{4}\right)$ and evaporated. The residue was purified by flash chromatography on silica gel to give title compound 5 (366 mg, 96\% yield). $[\alpha]_{\mathrm{D}}{ }^{20}-48.04$ (c 5.05, $\left.\mathrm{CHCl}_{3}\right) ;{ }^{1} \mathrm{H} \mathrm{NMR}\left(\mathrm{CDCl}_{3}\right)$ (multiple rotamers): $\delta 0.92(3 \mathrm{H}, \mathrm{t}$, $\mathrm{J}=7.4 \mathrm{~Hz}) ; 0.96(3 \mathrm{H}, \mathrm{d}, \mathrm{J}=6.7 \mathrm{~Hz}) ; 1.22(3 \mathrm{H}, \mathrm{d}, \mathrm{J}=6.5 \mathrm{~Hz}) ; 1.38 \& 1.42(9 \mathrm{H}, \mathrm{s}) ; 1.46 \sim 1.54 \& 1.18(2 \mathrm{H}$, $\mathrm{m}) ; 2.21 \sim 1.91(5 \mathrm{H}, \mathrm{m}) ; 2.87 \sim 3.04(2 \mathrm{H}, \mathrm{m}) ; 3.75 \sim 3.41 \& 3.18 \sim 3.08(2 \mathrm{H}, \mathrm{m}) ; 3.79(3 \mathrm{H}, \mathrm{s}) ; 4.18(1 \mathrm{H}$, $\mathrm{m}) ; 4.04 \sim 3.97(1 \mathrm{H}, \mathrm{m}) ; 4.30 \sim 4.34(1 \mathrm{H}, \mathrm{m}) ; 4.48 \sim 4.68(3 \mathrm{H}, \mathrm{m}) ; 5.34 \sim 5.41(1 \mathrm{H}, \mathrm{m}) ; 7.07 \sim 7.10(2 \mathrm{H}$, $\mathrm{m}) ; 7.08 \sim 7.32(5 \mathrm{H}, \mathrm{m}) ;{ }^{13} \mathrm{C} \mathrm{NMR}\left(\mathrm{CDCl}_{3}\right)$ (multiple rotamers): $\delta 11.2 ; 15.7 ; 18.8 ; 25.2 ; 25.2$; 27.9; 28.4; 36.4; 39.5; 47.6; 52.3; 53.8; 58.5; 58.515; 60.8; 68.6; 79.8; 127.0; 128.7; 129.4; 136.6; 155.2; 170.4; 171.4; 171.5; 172.4; IR (cm $\left.{ }^{-1}\right): 3427,3325,3015,2978,1724,1659,1504$, 1438; EIMS: 590, 546, 473, 446, 430, 382, 330, 345, 278, 190, 153, 173, 136, 107; HRMS (EI): calcd for $\mathrm{C}_{30} \mathrm{H}_{46} \mathrm{~N}_{4} \mathrm{O}_{8}$ 590.3316, found 590.3306. 
$N$-Teoc-L-Phe-L-Pro-L-Thz-L-Phe-L-Pro- L-Ile- L-aThr methyl ester (4a). To $N$-Boc-LPhe-L-Pro-L-Ile-L- $a$ Thr methyl ester (5) (127.6mg, $0.216 \mathrm{mmol})$ in THF (2 mL) was added a solution of lithium hydroxide $(48.0 \mathrm{mg}, 2.0 \mathrm{mmol})$ in $2: 1$ methanol/ $\mathrm{H}_{2} \mathrm{O}(3 \mathrm{~mL})$ and the reaction mixture was stirred at room temperature for 24 hours, acidified with $1 \mathrm{M} \mathrm{HCl}$ at $0^{\circ} \mathrm{C}$, and extracted with ethyl acetate $(3 \times 30 \mathrm{~mL})$. The organic extracts were dried $\left(\mathrm{Na}_{2} \mathrm{SO}_{4}\right)$ and concentrated to obtain the product acid, which was used without further purification.

$N$-Teoc-L-Phe-L-Pro-Thz methyl ester (6) (117.8 mg, $0.234 \mathrm{mmol}$ ) was dissolved in 1:1 TFA/ $\mathrm{CH}_{2} \mathrm{Cl}_{2}(2 \mathrm{~mL})$ at $0^{\circ} \mathrm{C}$ and stirred at room temperature for 2 hours. The solvent was removed under reduced pressure and the residue was redissolved in $\mathrm{CH}_{2} \mathrm{Cl}_{2}$ and reconcentrated repeatedly to remove excess TFA. The dry sample was stored under high vacuum to give the TFA salt which was used without further purification. This salt was combined with the free acid derived from 5 in THF $(10 \mathrm{~mL})$ at $0^{\circ} \mathrm{C}$, and HOAt $(123.9 \mathrm{mg}, 0.91 \mathrm{mmol})$, EDCI $(171.3 \mathrm{mg}, 0.890 \mathrm{mmol})$ and NMM $(0.35 \mathrm{~mL}, 2.273 \mathrm{mmol})$ were added. The reaction mixture was stirred at $0^{\circ} \mathrm{C}$ for 1 hour and then stirred at room temperature for further 36 hours. Following dilution with $\mathrm{CH}_{2} \mathrm{Cl}_{2}(20 \mathrm{~mL})$ the solution was washed with saturated sodium hydrogen carbonate $(5 \mathrm{~mL})$, ammonium chloride $(5 \mathrm{~mL})$, brine $(5 \mathrm{~mL})$ and dried over sodium sulfate. Removal of the solvent in vacuo followed by chromatography on silica gel afforded the title compound 4a (174mg, 90\% yield). [ $\alpha]_{\mathrm{D}}{ }^{20}-68.04$ (c 7.05, $\left.\mathrm{CHCl}_{3}\right) ;{ }^{1} \mathrm{H} \mathrm{NMR}\left(\mathrm{CDCl}_{3}\right)$ (multiple rotamers): $\delta 0.90 \sim 081(6 \mathrm{H}, \mathrm{m}) ; 1.34 \sim 0.93(5 \mathrm{H}, \mathrm{m})$; 1.39(9H, s); 1.71 1.46(2H, m); 2.35 1.86(5H, m); 3.22 2.88(5H, m); 3.56 3.34(2H, m); 3.79 3.65(5H,m); 4.35 4.11(3H, m); 4.53 4.44(1H, m); 4.75 4.64(2H, m); 5.08 4.94(2H, m); 5.28 5.25(1H, m); 5.44 5.41(1H, m); 7.53 76.98(12H, m); 7.93 7.84(1H, m); 7.94(1H, s); ${ }^{13} \mathrm{C}$ NMR $\left(\mathrm{CDCl}_{3}\right)$ (multiple rotamers): $\delta 11.7 ; 15.1 ; 17.6 ; 20.1 ; 24.6 ; 25.0 ; 27.8 ; 28.3 ; 31.0 ; 36.5$; 38.3; 39.1; 47.3; 47.5; 51.9; 52.1; 52.5; 58.2; 58.5; 60.2; 63.8; 74.2; 79.5; 127.0; 128.5; 128.6; 128.8; 128.9; 129.3; 129.4; 136.0; 136.1; 148.1; 156.4; 160.6; 168.3; 170.2, 171.1; 171.2; 171.3; 172.4; IR $\left(\mathrm{cm}^{-1}\right)$ : 3426, 3015, 2978, 1724, 1710, 1659, 1504; FABMS: 941(MH+Na); 919(MH);819.

$N$-Teoc-L-Phe-L-Pro-Thz-L-Phe-L-Pro-L-Ile-L-aThr methyl ester (4b). To $N$-Teoc-L-Phe-LPro-Thz methyl ester (6) (138 mg, $0.274 \mathrm{mmol}$ ) in THF (2 mL) was added a solution of lithium hydroxide (100 mg, $4.17 \mathrm{mmol})$ in $2: 1$ methanol/ $\mathrm{H}_{2} \mathrm{O}(3 \mathrm{~mL})$ and the reaction mixture was stirred at room temperature for 24 hours, acidified with $1 \mathrm{M} \mathrm{HCl}$, and extracted with ethyl acetate (3 x $30 \mathrm{~mL}$ ). The organic extracts were dried $\left(\mathrm{Na}_{2} \mathrm{SO}_{4}\right)$ and concentrated to obtain the product acid, which was used without further purification.

$\boldsymbol{N}$-Boc-L-Phe-L-Pro-L-Ile-L-aThr methyl ester (5). (156 mg, $0.264 \mathrm{mmol}$ ) was dissolved in 1:1 TFA $/ \mathrm{CH}_{2} \mathrm{Cl}_{2}(2 \mathrm{~mL})$ at $0^{\circ} \mathrm{C}$ and stirred at room temperature for 2 hours. The solvent was removed under reduced pressure and the residue was redissolved in $\mathrm{CH}_{2} \mathrm{Cl}_{2}$ and reconcentrated repeatedly to remove excess TFA. The dry sample was stored under high vacuum to give the TFA salt which was used without further purification. This salt was combined with the free acid derived from $\mathbf{6}$ in THF (10 mL) at $0^{\circ} \mathrm{C}$, and HOAt (0.188 g, $\left.1.38 \mathrm{mmol}\right)$, EDCI (250 mg, $\left.1.3 \mathrm{mmol}\right)$ and NMM $(0.73 \mathrm{ml}, 6.6 \mathrm{mmol})$ were added. The reaction mixture was stirred at $0^{\circ} \mathrm{C}$ for 1 hour and then stirred at room temperature for further 36 hours. Following dilution with $\mathrm{CH}_{2} \mathrm{Cl}_{2}(20 \mathrm{~mL})$ the 
solution was washed with saturated sodium hydrogen carbonate $(5 \mathrm{~mL})$, ammonium chloride $(5 \mathrm{~mL})$, brine $(5 \mathrm{~mL})$ and dried over sodium sulfate. Removal of the solvent in vacuo followed by chromatography on silica gel afforded the title compound $\mathbf{4 b}$ (228 mg, 88\% yield). $[\alpha]_{\mathrm{D}}{ }^{20}-59.7$ (c 10.0, $\left.\mathrm{CHCl}_{3}\right) ;{ }^{1} \mathrm{H}$ NMR $\left(\mathrm{CDCl}_{3}\right)$ (multiple rotamers): $\delta 0.14 \sim-0.15(9 \mathrm{H}, \mathrm{m}) ; 0.97 \sim 0.80(6 \mathrm{H}, \mathrm{m})$; 1.23 1.04(5H, m); 1.70 1.45(3H, m); 2.32 1.87(7H, m); 3.76 3.61(5H, m); 3.56 2.87(6H, m); 4.16 3.98(3H, m); 4.37 4.30(1H, m); 4.59 4.44(1H, m); 4.66 4.60(1H, m); 4.73 4.69(1H, m); 4.89 5.08(1H, m); 5.58 5.59(1H, m); 7.04 7.30(12H, m); 7.92 7.84(2H, m); ${ }^{13} \mathrm{C}$ NMR $\left(\mathrm{CDCl}_{3}\right)$ (multiple rotamers): $\delta-1.6$; 11.2; 15.5; 17.6; 18.8; 24.5; 24.8; 25.0; 28.0; 31.0; 36.9; 38.9\&38.0; 38.8; 47.1; 47.6; 52.1; 52.4; 53.2; 58.0; 58.1; 58.1; 60.5; 63.4; 68.3; 123.9; 126.9; 127.1; 128.4; 128.6; 129.2; 129.3; 135.9; 136.0; 148.5; 156.2; 160.6; 170.2; 170.9; 171.3; 171.43;. 171.8; 171.4; IR $\left(\mathrm{cm}^{-1}\right)$ : 3425, 3035, 3006, 1732, 1650, 1505, 1250; FABMS: $985(\mathrm{M}+23)$, 963(M+1), 919, 891,819, 672, 620, 563, 473.

\section{Cyclo[L-Phe-L-Pro-Thz-L-Phe-L-Pro-L-Ile-L-aThr] (3a \& 3b) ${ }^{21}$}

Method one: Prepared from 4a. $N$-Teoc-Phe-L-Pro-Thz-L-Phe-L-Pro-L-Ile-L- $a$ Thr methyl ester (4a) (113 mg, $0.123 \mathrm{mmol})$ in THF (1 mL) was added a solution of lithium hydroxide (24 mg, $1 \mathrm{mmol})$ in 2:1 methanol/ $\mathrm{H}_{2} \mathrm{O}(1.5 \mathrm{~mL})$ and the reaction mixture was stirred at room temperature for 4 hours, acidified with $1 \mathrm{M} \mathrm{HCl}$, and extracted with ethyl acetate $(3 \times 30 \mathrm{~mL})$. The organic extracts were dried $\left(\mathrm{Na}_{2} \mathrm{SO}_{4}\right)$ and concentrated. The residue was re-dissolved in 1:1 TFA/ $\mathrm{CH}_{2} \mathrm{Cl}_{2}$ $(2 \mathrm{~mL})$ at $0^{\circ} \mathrm{C}$ and stirred at room temperature for 2 hours. The solvent was removed under reduced pressure and the residue was redissolved in $\mathrm{CH}_{2} \mathrm{Cl}_{2}$ and reconcentrated repeatedly to remove excess TFA. The residue was re-dissolved in DMF $(80 \mathrm{~mL})$ and DIPEA $(0.174 \mathrm{ml}$, $1.23 \mathrm{mmol}$ ) was added, followed by HATU (56 $\mathrm{mg}, 0.1473 \mathrm{mmol}$ ). The reaction mixture was stirred at $0^{\circ} \mathrm{C}$ for 1 hour and then at room temperature for further 80 hours. The solvent was evaporated and the residue was purified by flash chromatography on silica gel to give cyclopeptides 3 (44 mg, 46\% yield) as a mixture of conformational isomers (3a:3b $=1: 1.3$ ).

Method two: Prepared from 4b. L-Boc-Phe-L-Pro-Thz-L-Phe-L-Pro-L-Ile-L-aThr methyl ester (4b) (30 mg, $0.032 \mathrm{mmol})$ in THF $(1 \mathrm{ml})$ was added a solution of lithium hydroxide $(6.1 \mathrm{mg}$, $0.256 \mathrm{mmol})$, in $2: 1$ methanol $/ \mathrm{H}_{2} \mathrm{O}(1.5 \mathrm{ml})$ and the solution mixture was stirred at room temperature for 4 hours, The solution was neutralized with diluted $\mathrm{HCl}$ solution $(1 \mathrm{M})$ and then extracted by ethyl acetate $(3 \times 10 \mathrm{ml})$. The combined organic layers were dried $\left(\mathrm{Na}_{2} \mathrm{SO}_{4}\right)$ and concentrated. The residue was re-dissolved in 1:1 TFA/ $\mathrm{CH}_{2} \mathrm{Cl}_{2}(2 \mathrm{ml})$ at $0^{\circ} \mathrm{C}$ and stirred at room temperature for 2 hours. The solvent was removed under reduced pressure and the residue was redissolved in $\mathrm{CH}_{2} \mathrm{Cl}_{2}$ and reconcentrated repeatedly to remove excess TFA. The residue was redissolved in DMF $(10 \mathrm{ml})$, and NMM $(0.017 \mathrm{ml}, 0.153 \mathrm{mmol})$ was added, followed by HATU (56 mg, $0.147 \mathrm{mmol}$ ). The reaction mixture was stirred at room temperature for 80 hours. The solvent was evaporated and the residue was purified by flash chromatography on silica gel to give cyclopeptides 3 (2.5 mg, 10\% yield) as a mixture of conformational isomers (3a:3b=1:1.3). IR ( $\left.\mathrm{cm}^{-1}\right)$ : 3440, 3023, 2985, 2933, 1731, 1645, 1374, 1226, 1046, 783, 748; EIMS: 767(M-18), 
729, 676, 443, 207, 151, 150, 153, 136; HRMS (M-18): calcd for $\mathrm{C}_{41} \mathrm{H}_{49} \mathrm{~N}_{7} \mathrm{O}_{6} \mathrm{~S}$ 767.3465, found 767.3461. $[\alpha]_{\mathrm{D}}{ }^{20}-86.55$ (с 1.1, $\left.\mathrm{CHCl}_{3}\right)$

cis/cis isomer 3a. ${ }^{1} \mathrm{H}$ NMR: $\left(\mathrm{CDCl}_{3}\right) \delta$ 0.92(3H, t, J=7.0 Hz); 0.94(3H, d, J=6.3 Hz); 1.17 2.44 $(22 \mathrm{H}, \mathrm{m}) ; 3.10(2 \mathrm{H}, \mathrm{m}) ; 3.13 \& 3.22(2 \mathrm{H}, \mathrm{m}) ; 3.72 \sim 2.88(8 \mathrm{H}, \mathrm{m}) ; 3.88(1 \mathrm{H}, \mathrm{m}) ; 4.30(1 \mathrm{H}, \mathrm{m})$; 4.33(1H, m); 4.90(1H, m); 5.07(2H, m); 6.69(1H, d, J=6.6 Hz); 7.39 7.05(12H, m). 7.72(1H, d, $\mathrm{J}=1.9 \mathrm{~Hz}) ; 7.98(1 \mathrm{H}, \mathrm{m}) ; 7.93(1 \mathrm{H}, \mathrm{s}) ;{ }^{13} \mathrm{C} \mathrm{NMR:}\left(\mathrm{CDCl}_{3}\right) \delta 11.8 ; 16.2 ; 18.1 ; 21.2 ; 21.9 ; 24.3$; 31.3; 34.0; 35.5; 38.3; 38.5; 46.0; 47.4; 53.8; 54.8; 58.1; 59.0; 59.9; 61.4; 70.4; 124.3; 127.0; 127.8; 128.5; 129.1; 129.3; 129.3; 135.3; 136.7; 148.1; 161.5; 168.3; 169.8; 170.5 170.6; 171.2; 171.9

cis/trans isomer 3b. ${ }^{1} \mathrm{H}$ NMR: $\left(\mathrm{CDCl}_{3}\right) \delta 0.88(3 \mathrm{H}, \mathrm{t}, \mathrm{J}=7.3 \mathrm{~Hz}) ; 0.90(3 \mathrm{H}, \mathrm{d}, \mathrm{J}=6.3 \mathrm{~Hz})$; 2.44 1.17(22H, m); 3.00(2H, m); 3.16\&3.32(2H, m); 3.72 2.88(8H, m); 4.13(1H, m); 4.13(1H, $\mathrm{m}) ; 4.16(1 \mathrm{H}, \mathrm{m}) ; 4.39(1 \mathrm{H}, \mathrm{m}) ; 4.56(1 \mathrm{H}, \mathrm{m}) ; 4.69(2 \mathrm{H}, \mathrm{m}) ; 5.89(1 \mathrm{H}, \mathrm{d}, \mathrm{J}=10.1 \mathrm{~Hz}) ; 6.84(1 \mathrm{H}, \mathrm{d}$, $\mathrm{J}=8.1 \mathrm{~Hz}) ; 7.39 \sim 7.05(12 \mathrm{H}, \mathrm{m}) ; 7.93(1 \mathrm{H}, \mathrm{m}) ; 9.13(1 \mathrm{H}, \mathrm{d}, \mathrm{J}=9.5 \mathrm{~Hz}) ;{ }^{13} \mathrm{C} \mathrm{NMR:}\left(\mathrm{CDCl}_{3}\right) \delta 11.5$; $16.1 ; 20.1 ; 22.3 ; 25.1 ; 25.8 ; 29.7 ; 34.1 ; 36.8 ; 38.1 ; 40.6 ; 45.7 ; 46.5 ; 52.9 ; 53.4 ; 56.5 ; 57.4 ;$ 58.8; $62.9 ; 66.3 ; 123.9 ; 127.1 ; 127.7 ; 128.7 ; 129.7 ; 129.3 ; 129.5 ; 135.0 ; 136.5 ; 150.3 ; 160.9 ; 169.5 ;$ $170.8 ; 170.9 ; 171.0 ; 171.6 ; 171.9$

cis, cis-Ceratospongamide (1). To cyclo[L-Phe-L-Pro-Thz-L-Phe-L-Pro-L-Ile-L-aThr] (3a and 3b, $16 \mathrm{mg}, 0.2 \mathrm{mmol})$ in dichloromethane $(2 \mathrm{~mL})$ at $-40^{\circ} \mathrm{C}$, Deoxo-Fluor $(0.02 \mathrm{ml}, 0.15 \mathrm{mmol})$ was added. The reaction mixture was stirred at this temperature for 2 hours and then quenched with methanol $(0.5 \mathrm{~mL})$. The reaction mixture was allowed to warm to room temperature. Removal of the solvent in vacuo followed by chromatography on silica gel afforded cis, cisceratospongamide 1 (13.5 mg, 89\% yield). $[\alpha]_{\mathrm{D}}{ }^{20}-88.56$ (с $\left.0.8, \mathrm{CHCl}_{3}\right) ;{ }^{1} \mathrm{H} \mathrm{NMR}:\left(\mathrm{CDCl}_{3}\right)$ $\delta 0.84(3 \mathrm{H}, \mathrm{d}, \mathrm{J}=6.9 \mathrm{~Hz}) ; 0.89\left(3 \mathrm{H}, \mathrm{q}, \mathrm{J}_{1}=7.4 \mathrm{~Hz}, \mathrm{~J}_{2}=15.6 \mathrm{~Hz}\right) ; 1.13 \& 1.64(2 \mathrm{H}, \mathrm{m}) ; 1.29(3 \mathrm{H}$, d, $\mathrm{J}=6.2 \mathrm{~Hz}) ; 1.45 \& 1.08(2 \mathrm{H}, \mathrm{m}) ; 1.76(1 \mathrm{H}, \mathrm{m}) ; 1.92(2 \mathrm{H}, \mathrm{m}) ; 2.10 \& 2.33(2 \mathrm{H}, \mathrm{m}) ; 2.35 \& 1.90(2 \mathrm{H}$, m); $2.88\left(1 \mathrm{H}, \mathrm{dd}, \mathrm{J}_{1}=10.9 \mathrm{~Hz}, \mathrm{~J}_{2}=11.4 \mathrm{~Hz}, \mathrm{~J}_{3}=12.6 \mathrm{~Hz}\right) \& 3.50\left(1 \mathrm{H}, \mathrm{dd}, \mathrm{J}_{1}=5.4 \mathrm{~Hz}, \mathrm{~J}_{2}=8.3 \mathrm{~Hz}\right.$; $\left.\mathrm{J}_{3}=11.7 \mathrm{~Hz}\right) ; 2.84\left(1 \mathrm{H}, q d, \mathrm{~J}_{1}=8.0 \mathrm{~Hz} ; \mathrm{J}_{2}=7.9 \mathrm{~Hz}, \mathrm{~J}_{3}=13.2 \mathrm{~Hz}\right) \& 3.03\left(1 \mathrm{H}, q d, \mathrm{~J}_{1}=7.5 \mathrm{~Hz}, \mathrm{~J}_{2}=7.0\right.$ $\left.\mathrm{Hz} ; \mathrm{J}_{3}=13.6 \mathrm{~Hz}\right) ; 3.17\left(1 \mathrm{H}\right.$, dd, $\left.\mathrm{J}_{1}=1.8 \mathrm{~Hz}, \mathrm{~J}_{2}=9.1 \mathrm{~Hz}\right) ; 3.64(1 \mathrm{H}, \mathrm{T}, \mathrm{J}=6.6 \mathrm{~Hz}) ; 3.72 \& 3.46(2 \mathrm{H}, \mathrm{m})$; $3.96(1 \mathrm{H}, \mathrm{m}) ; 3.96 \& 3.56(2 \mathrm{H}, \mathrm{m}) ; 4.66\left(1 \mathrm{H}, \mathrm{qd}, \mathrm{J}_{1}=1.8 \mathrm{~Hz}, \mathrm{~J}_{2}=4.3 \mathrm{~Hz} ; \mathrm{J}_{3}=9.6 \mathrm{~Hz}\right) ; 4.76(1 \mathrm{H}, \mathrm{q}$, $\left.\mathrm{J}_{1}=6.3 \mathrm{~Hz}, \mathrm{~J}_{2}=12.5 \mathrm{~Hz}\right) ; 4.81\left(1 \mathrm{H}, \mathrm{q}, \mathrm{J}_{1}=8.0 \mathrm{~Hz}, \mathrm{~J}_{2}=16.0 \mathrm{~Hz}\right) ; 5.23(1 \mathrm{H}, \mathrm{t}, \mathrm{J}=6.0 \mathrm{~Hz}) ; 6.68(1 \mathrm{H}, \mathrm{d}$, $\mathrm{J}=9.7 \mathrm{~Hz}) ; 6.81(1 \mathrm{H}, \mathrm{d}, \mathrm{J}=8.9 \mathrm{~Hz}) ; 7.17(3 \mathrm{H}, \mathrm{m}) ; 7.20(2 \mathrm{H}, \mathrm{m}) ; 7.28(3 \mathrm{H}, \mathrm{m}), 7.33(2 \mathrm{H}, \mathrm{m})$; 8.19(1H, d, J=4.5 Hz); 8.05(1H, s); ${ }^{13} \mathrm{C}$ NMR: $\left(\mathrm{CDCl}_{3}\right) \delta 11.6 ; 15.5 ; 21.3 ; 21.4 ; 21.8 ; 24.6$; 31.0; 35.0; 38.1; 39.0; 40.5; 46.4; 46.6; 51.4; 52.0; 53.7; 59.6; 61.2; 73.6; 81.4; 124.2; 126.6; 127.4; 128.1; 128.9; 129.4; 129.4; 136.0; 136.9; 148.6; 159.4; 168.7; 169.7; 169.8; 169.9; 170.4; 171.4; IR ( $\left.\mathrm{cm}^{-1}\right): 3440,3023,2985,2933,1731,1645,1374,1226,1046,783,748$; EIMS: 767, 676, 663, 647, 368, 151, 153, 136; HRMS(EI): calcd for $\mathrm{C}_{41} \mathrm{H}_{49} \mathrm{~N}_{7} \mathrm{O}_{6} \mathrm{~S}$ 767.3465, found 767.3461. 


\section{Acknowledgements}

We thank the support from the Area of Excellence Scheme (established under the University Grants Committee of the Hong Kong Special Administrative Region), The University of Hong Kong and The Hong Kong Polytechnic University.

\section{References and Notes}

1. (a) Humphrey, J. M.; Chamberlin, A. R. Chem. Rev. 1997, 97, 2243 and references cited therein. (b) Wipf, P. Chem Rev. 1995, 95, 2115 and references cited therein.

2. Tan, T.; Williamson, R. T.; Gerwick, W. H. J. Org. Chem. 2000, 65, 419.

3. Preliminary communication: "Seventh Symposium on Chemistry Postgraduate Research in Hong Kong” 29, April 2000, Hong Kong University of Science and Technology

4. Two total syntheses of ceratospongamide have been reported: (a) Deng, S. J.; Taunton, J. J. Am. Chem. Soc. 2002, 124, 916. (b) Yokokawa, F.; Sameshima, H.; Shioiri, T. Synlett 2001, 986. (c) Yokokawa, F.; Sameshima, H.; In, Y.; Minoure, K.; Ishida, T.; Shioiri, T. Tetrahedron 2002, 58, 8127.

5. Hamada, Y.; Kato, S.; Shiori, T. Tetrahedron Lett. 1985, 26, 3223.

6. Boden, C.; Pattenden, G. Tetrahedron Lett. 1994, 35, 8271.

7. Adrián, F.; Burguete, M. I.; Luis, S. V.; Miravet, J. F.; Querol, M.; García-España, E. Tetrahedron Lett. 1999, 40, 1039.

8. Boden, C. D. J.; Pattenden, G.; Ye, T. Synlett. 1995, 417 and references cited therein.

9. Cava, M. P.; Levinson, M. I. Tetrahedron 1985, 41, 5061.

10. Ishihara, H.; Shimura, K. FEBS Lett. 1988, 226, 319.

11. (a) Wipf, P.; Miller, C. P. Tetrahedron Lett. 1992, 33, 907. (b) Wipf, P.; Miller, C. P. J. Am. Chem. Soc. 1992, 114, 10975. (c) Wipf, P.; Miller, C. P. J. Org. Chem. 1993, 58, 1575.

12. Carpino, L. A. J. Am. Chem. Soc. 1993, 115, 4397.

13. The ratio of $\mathbf{3 a}$ and $\mathbf{3 b}$ is determined by integration of Phe-1 residue's $\mathrm{NH}$ peak of each conformational isomer.

14. (a) Chen, S. Q.; Xu, J. C. Tetrahedron Lett. 1991, 32, 6711. (b) Deng, J. G.; Hamada, Y.; Shioiri, T; Matsunaga, S.; Fusetani, N. Angew. Chem. Int. Ed. Eng. 1994, 33, 1729. (c) Deng, J. G.; Hamada, Y.; Shioiri, T. Synthesis 1998, 627.

15. Knorr, R.; Trzeciak, A.; Bannwarth, W.; Gillessen, D. Tetrahedron Lett. 1989, 30, 1927.

16. Coste, J.; Le-Nguyen, D.; Castro, B. Tetrahedron Lett. 1990, 31, 205.

17. Philips, A. J.; Uto, Y.; Wipf, P.; Reno, M. T.; Williams, D. R., Org. Lett. 2000, 2, 1165.

18. (a) Schmidt, U.; Beutler, U.; Lieberknecht, A., Angew. Chem. Int. Ed. Engl. 1989, $28,333$.

(b) Schmidt, U.; Langner, J. J. Peptide Res. 1997, 49, 67.

19. (a) Siemion, I. Z.; Wieland, T.; Pook, K. H., Angew. Chem. Int. Ed. Engl. 1975, 14, 702. (b) Kessler, H. Angew. Chem. Int. Ed. Engl. 1982, 21, 512. 
20. Deng and Taunton have observed that cyclopeptide 3 presents at least three conformers in $\mathrm{CDCl}_{3}$ based on a $1 \mathrm{D}$ proton NMR spectrum. See reference 4(a).

21. For macrocyclization of linear precursor derived from $\mathbf{4 b}$ according to same procedure with various reagents, please see the discussion section. 